\title{
First Report of White Grub Exopholis hypoleuca Wiedemann (Coleoptera: Scarabaeidae) on Eucalyptus spp. (Myrtaceae) Plantations
}

\author{
Irfan Pasaribu $^{1 *}$, Heri Sunarko ${ }^{1}$, Jupiter Israel Muro Abad ${ }^{1}$, Srikumar Koda Kkadan ${ }^{2}$, \\ Wagner de Souza Tavares ${ }^{2}$, Álvaro Durán ${ }^{2}$ \\ ${ }^{1}$ PT. Toba Pulp Lestari (TPL), Porsea, North Sumatera, Indonesia, 22384 \\ ${ }^{2}$ Asia Pacific Resources International Holdings Ltd. (APRIL), Riau Andalan Pulp and Paper (RAPP), Pangkalan \\ Kerinci, Riau 28300, Indonesia \\ *Corresponding author. E-mail: irfan.pasaribu9@gmail.com
}

\begin{abstract}
Eucalyptus spp. (Myrtaceae) is planted in North Sumatera, Indonesia for pulpwood production. This plant is prone to be attacked by insects that are pests in annual crops. The objective of this study was to identify white grub species (Coleoptera: Scarabaeidae) on Eucalyptus trees in private company PT. Toba Pulp Lestari (TPL) in Aek Nauli Sector, Simalungun District, North Sumatera, Indonesia. White grubs on Eucalyptus spp. were collected from field and brought to Entomology Laboratory in Porsea. Grubs were reared successfully in the soil mixed of soil with cocopeat. White grub was identified as Exopholis hypoleuca (Wiedmann) based on the analysis of the external morphology of its larvae and adult's wing venation.
\end{abstract}

Keywords: external morphology, North Sumatera, pulpwood production

\section{INTRODUCTION}

The beetle belongs to the dominant order of animal Kingdom Coleoptera. Several beetles are a serious pest of agricultural and forestry plantations. The beetle attack almost all type of wood that is living plants as well as processed fibre, grains and wood product [1]. Almost all part of the tree can be attacked by the beetle.

The white grub's family (Coleoptera: Scarabaeidae) is the second largest family which includes over 30,000 species. These grubs are the soil inhibiting and root feeding immature stages of scarab beetles of which larval stage is destructive in nature [2]. White grub is broad, fleshly, whitish or greyish white and the body is curved in the form of "C" letter. White grub or scarab larvae damage practically all type of crop. The larvae is feeding the root of the plant or grass. However, their damage to taproot crops, specially the leguminous ones, is more serious as they do not merely cut the taproot which the plants hardly recover from, but they also feed away the nodules which cause the plants suffer from proper nitrogen supply [3].

The white grub in Indonesia reported as pest in the rice, corn, sugarcane and several annual crops $[4,5]$. The symptoms of white grub damage on the plant are leaves yellowing and the plant become dry [6].

Eucalyptus spp. is annual type of plants that grow and develop in Indonesian forestry. Many eucalypts species find the weather and environmental conditions in Indonesia suitable to develop, and some of the species are native from East Indonesia. A controlling strategy for this larva is required to keep the Exopolis hypoleuca from Eucalyptus spp. However, further identification of the larva is still not determined. Hence, this study aimed to identify the white grub that attack Eucalyptus root in PT. Toba Pulp Lestari, North Sumatera.

\subsection{Materials and Methods}

\subsubsection{Collection of white grub}

The survey and collection of white grub (Coleoptera: Melolonthidae) were carried out in Aek Nauli eucalypts plantation, North Sumatera, Indonesia. The location altitude was 1000-1100 m asl. Larvae were collected from the symptomic eucalypts (Figure 1).

Sampling was conducted from August to November 2018 which were during the peak of larvae populations. As many as 10 larvae per area were collected and put into a labelled plastic container containing soil, then were brought to the Entomology Laboratory in Porsea to be identified. Rearing was conducted until the larvae turned into pupae and proceeded until adult emerged from pupae. Egg phase was 17-20 days, then followed with larvae phase was 8-9 months, pupae phase was 30 days, and adult phase around 2 month old. 

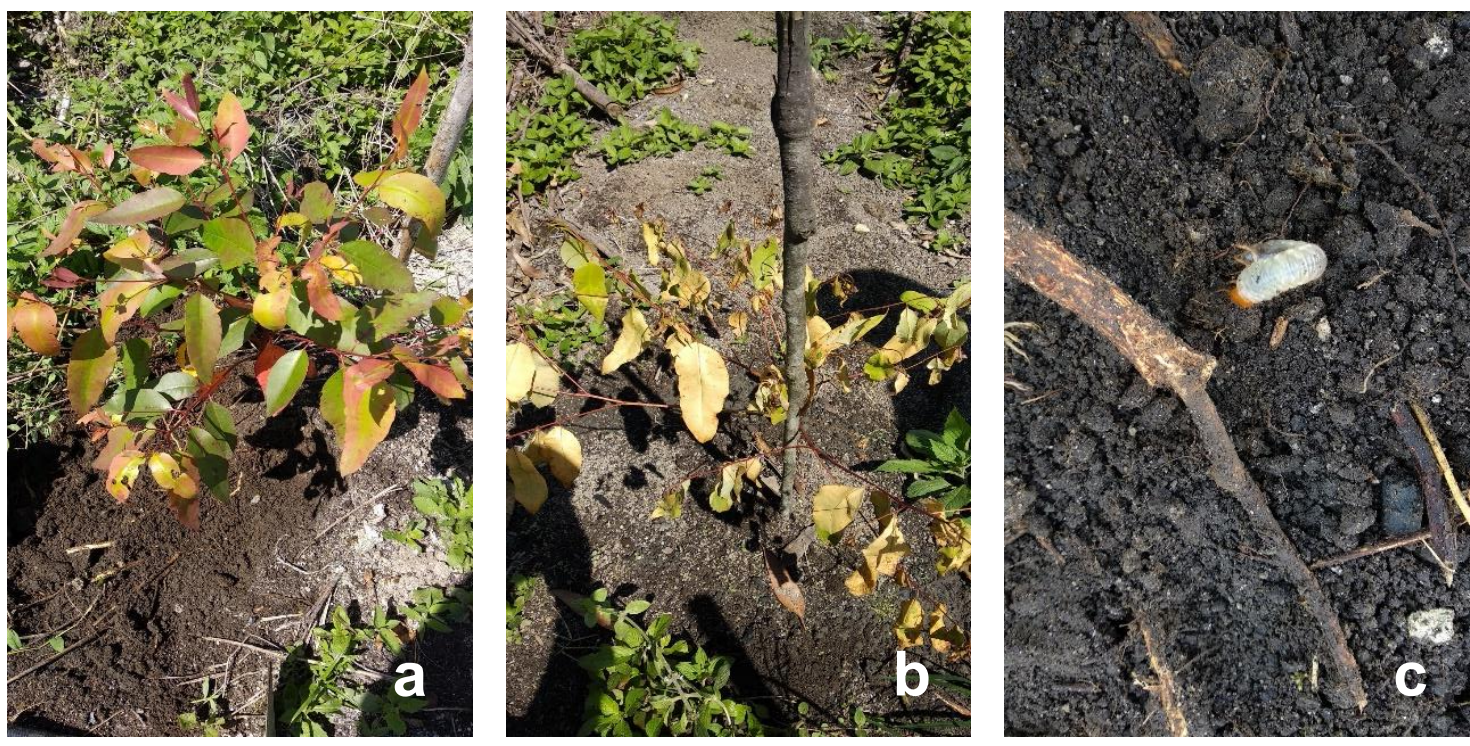

Figure 1 Symptom of white grubs damage: (a) initial damage, leaves yellowing (b) developed damage, leaves dried (c) root condition with the white grub

\subsubsection{Rearing of white grub}

As many as 5 larvae were put into a plastic container containing cocopeat and soil as media and wood litters as feed for white grub. Each container was sprayed with clean water every day to prevent from dried.

\subsubsection{Identification}

Identification involved the morphological characteristics of larva and adult stages. The characteristic of larva was identified using Kalshoven identification key [4]. For the necessity of identification, larvae were cut into $1 \mathrm{~cm}$ long on the posterior of abdomen, then mounted on slides by heating the specimen in $\mathrm{KOH} 10 \%$ until the specimen became transparent. The specimen then soaked in ethanol $80 \%$ and proceeded in acid fuchsin. The activity was done under stereo microscope.

The adult's wing venation was identified using the Global Biodiversity Information Facility (GBIF) key [7]. The emerged adult from pupae was killed by using ethyl acetate gas. Then the wing was taken for identification.

\subsection{Our Contribution}

This paper presents the information that has not been reported based on case and assumtions in the eucalypts plantation area. Our purpose is to identify the insect that caused the damage in young eucalypts plants, so it is will useful to study more about its eco-biology. It would be used to find a good technique to control its population and reduce the damage in the plantation areas. Like a principle of integrated pest management (IPM), we should to know the insects we will control.

\subsection{Paper Structure}

The rest of the paper is organized as follows. Second section explained the damage and severity that caused by this insect in eucalypts plantation areas. Section 3 will presenter about econ-biology of this insect, include about behaviour and life time. This result will use for the control technique for future research, how to find a right control technique in the right time.

\section{RESULTS AND DISCUSSION}

The result showed that the species of white grub which attacked the eucalypts plantation in Aek Nauli was Exopholis hypoleuca (Coleoptera: Scarabaeidae).

The beetles were fed on tender leaves and went back to the soil for eggs laying. The annual life cycle of larvae is 8 to 10 months. There are three groups such as, annual white grub (massked chafer), japanese beetle and true white grub (May/June beetle) [10]. The most destructive genus of the Melolonthinae are Apogonia, Exopholis, Holotrichia, Leucopholis and Schizonycha $[8,9]$.

Based on the morphological characteristic of larvae it was confirmed as E. hypoleuca. Lateral patterns on grub's posterior end were used to determine the species. Central setae of the hair often in irregular rows. Between these rows there was small setae near the posterior margin (Figure 2 a). The characteristics of larvae showed that the anal selit was 


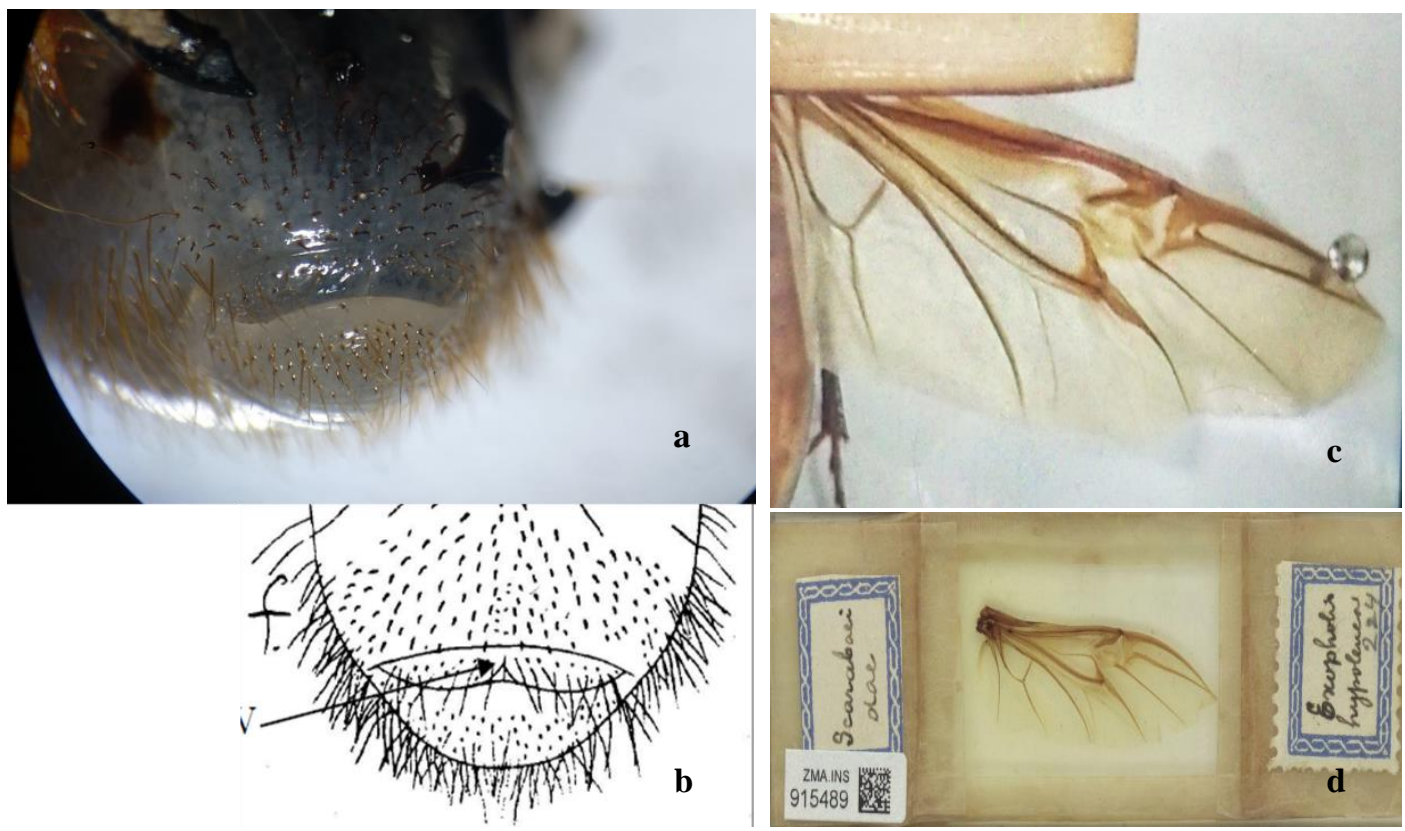

Figure 2 Morphological characteristics of E. hypoleuca: (a) posterior abdomen of larvae, (b) abdomen of larva from identification key [4] (c) Hindwings venation of adult from rearing (d) hindwings venation of adult from GBIF collection [7]

situated transverse (dorso-ventral). The larvae had three pairs of developed legs. Body was not fully extended, sometimes with a dorsal swell, almost unable to move on level surface, progression often only possible when lying on the side, feeding on roots.

The adults was brown, shiny light brown elytra with some dark brown color near the margin. The ventral side abdomen was white. This insect has less with fine short white hair. The antennae type was lammelate. The body size was about $25 \mathrm{~mm}$ (Figure 3 ) with the female size was bigger than male's. Vein of hindwings was simple (Figure $2 \mathrm{c}$ ). The vein was consisted of Medial Bridge, Bending Zone, Marginal Joint, Movable Vein Joint, Anal Anterior, Cubitus Anterior.
The larvae stage was more destructive than the adult on eucalypts plantation. The adults were found feeding on the leaves of Corymbia citriodora (family Myrtaceae) instead eucalypts. Sometimes $C$. citriodora was known as one of eucalypts species. This may be the first report of white grub on eucalypts plantation in North Sumatera.

\section{CONCLUSION}

The species of white grub which attacked the eucalypts plantation in Aek Nauli, North Sumatera is Exopholis hypoleuca. This may be the first report of white grub on

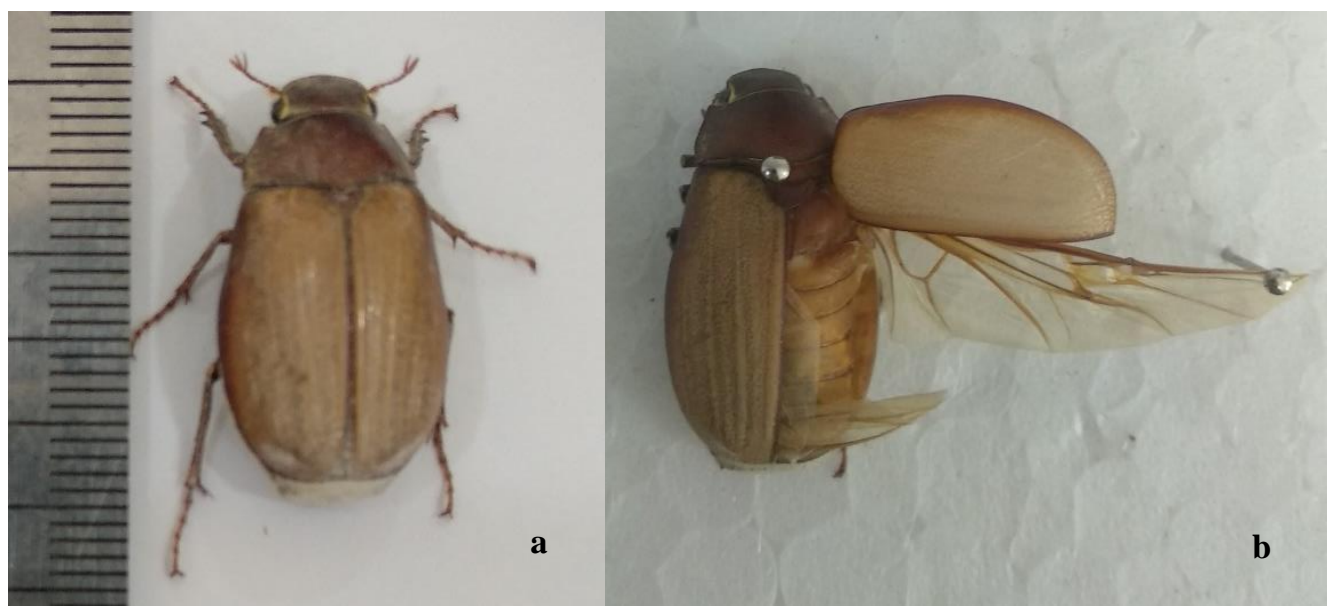

Figure 3 Adult of Exopholis hypoleuca: (a) elytra wings closed, (b) wing open 
[10] W.S. Cranshaw, Colorado State University. White Grub and Billbugs: Control in Home Lawns. Colorado State University, U.S. Department of Agriculture and Colorado counties cooperating. https://extension. colostate.eddocs/pubs/insect/05516.pdf
This work was supported by Research and Development of PT. Toba Pulp Lestari and PT. Riau Andalan Pulp and Paper. Our thanks Ervan Sumando Purba, Jeremia A. Hasugian, Riyanti Laura Pasaribu for field and laboratory assistance, to Adventris Hutagaol as a coordinator researcher.

\section{REFERENCES}

[1] G.P. Bhawane, A.B. Mamlayya, S.R. Wagh, A.K. Chaugule, Diversity of White grub beetles and their host range from Northern Western Ghats, Kolhapur district (MS) India, Bioscan. 7 (4) (2012) 589-596

[2] D.G. Khanal, C.Y. Dhoj, M. Sporleder, R.B. Thapa, Distribution of white grubs in three ecological domains of Nepal, J. Agric. Environ. 13 (41) (2012) 40-46

[3] V.V. Bajad, S.M. Dadmal, D.B. Undirwade, Diversity of white grub (Coleoptera: Scarabaeidae: Melolonthinae) from Maharashtra, Agric Update, 12 (5) (2017) 1363-1366

[4] L.G.E. Kalshoven, Pest of crops in Indonesia, (revisied \& Translated by P. A. Van Der Laan) Jakarta, PT. Ichtiar Baru-Van Hoove. 1981, 701

[5] T. Harjaka, Isolasi Jamur Entomopatogenik Metarhizium anisopliae pada hama ueret perusak akar padi gogo. Prosiding Seminar hasil penelitian pertanian fakultas pertanian UGM. Yogyakarta (id). 2006 pp. 200-205. http: //repository.ugm.ac.id/ digitasi/index.php?module=cari_hasilfull\&idbuku $=2857$

[6] S. Hartati, H. Sudarmo, Jarak pagar, menyerbuk silang atau menyerbuk sendiri. J. Infotek. 2 (10) (2007) 37

[7] [GBIF] Global Biodiversity Information Fasility. 2019. http:// medialib. naturalis.nl/ file /id/ ZMA. INS.915489/format/large

[8] C.F.C. Beeson, The ecology and control of the forestinsects of india and neighbouring countries. Dehra Dun. India (in): Bishen Singh, Mahendra Pal Singh, 1941

[9] K.S.S. Nair, Tropical forest insect pest, ecology, impact and management. U.K Cambridge University Press, 2007 